\title{
PENGARUH KOMISARIS INDEPENDEN, KOMITE AUDIT, KUALITAS AUDIT, KEPEMILIKAN INSTITUSIONAL DAN KEPEMILIKAN MANAJERIAL TERHADAP ASIMETRI INFORMASI
}

\section{THE INFLUENCE OF INDEPENDENT COMMISSIONERS, AUDIT COMMITTEE, AUDIT QUALITY, INSTITUTIONAL OWNERSHIP AND MANAGERIAL OWNERSHIP OF INFORMATION ASYMMETRY}

\author{
Linda Ayu Oktoriza \\ Dosen Universitas Semarang, \\ lindaayu@usm.ac.id \\ Amerti Irvin W \\ Dosen Universitas Semarang \\ Surjawati \\ Dosen Universitas Semarang
}

\begin{abstract}
ABSTRAK
Adanya ketidakterbukaan informasi dan adanya benturan kepentingan antara agen dan prinsipal menyebabkan tidak diungkapkannya semua informasi kepada publik secara jelas, terutama kepada para investor. tujuan penelitian yaitu untuk mengetahui pengaruh komisaris independen, komite audit, kualitas audit, kepemilikan institusional dan kepemilikan manajerial terhadap asimetri informasi.

Variabel dependen penelitian ini adalah asimetri informasi. Penelitian ini mengukur asimetri informasi menggunakan bid-ask spread. Variabel independen yang digunakan yaitu komisaris independen, komite audit, kualitas audit, kepemilikan institusional dan kepemilikan manajerial. Penelitian ini juga menyertakan variabel Kontrol yang digunakan dalam penelitian ini, yaitu: (1) ukuran perusahaan (size) yang diukur dengan total asset perusahaan; (2) volume perdagangan yaitu penutupan pasar bulanan yang kemudian dirata-rata dalam satu tahun,dan (3) varian return yang diukur dengan return saham. Data penelitian ini adalah perusahaan manufaktur yang terdaftar pada BEI selama tahun 2015 - 2017. Pengambilan sampel dilakukan dengan menggunakan metode purposive sampling. Berdasarkan kriteria pemilihan sampel tersebut diperoleh sampel 77 perusahaan.

Pada penelitian ini dapat disimpulkan bahwa komisaris independen, komite audit, kualitas audit, struktur kepemilikan institusional secara umum dapat mengurangi asimetri informasi. Sedangkan untuk struktur kepemilikan manajerial tidak terbukti berpengaruh terhadap asimetri informasi.

Kata kunci: Komisaris Independen, Komite Audit, Kualitas Audit, Kepemilikan Institusional dan Manajerial, Asimetri Informasi
\end{abstract}

\section{ABSTRACT}

Information disclosure and conflicts of interest between agents and principals have clearly not revealed all information to the public, especially to investors. the purpose of the research is to find out the influence of independent commissioners, audit committee, audit quality, institutional ownership and managerial ownership on information asymmetry.

The dependent variable of this study is information asymmetry. This study measures information asymmetry using a bid-ask spread. Independent variables used are independent commissioners, audit committees, audit quality, institutional ownership and managerial ownership. This study also included the Control variables used in this study, namely: (1) the size of the company (size) as measured by the total assets of the company; (2) trading volume ie monthly 
Dinamika Sosial Budaya, Vol 20, No. 1, Juni 2018, pp 50-56

p-ISSN: 1410-9859\& e-ISSN: 2580-8524

http://journals.usm.ac.id/index.php/jdsb

market closing which is then averaged in one year, and (3) variant of returns measured by stock returns. The data of this study are manufacturing companies listed on the Stock Exchange during 2015 - 2017. Sampling was done using purposive sampling method. Based on the sample selection criteria, 77 companies obtained samples.

In this study it can be concluded that independent commissioners, audit committees, audit quality, institutional ownership structures in general can reduce information asymmetry. As for the managerial ownership structure, it is not proven to have an effect on information asymmetry.

Keywords: Independent Commissioner, Audit Committee, Audit Quality, Institutional Ownership,Managerial Ownership, Information Asymmetry

\section{PENDAHULUAN}

\subsection{Latar Belakang Masalah}

Berdasarkan Statement of Financial Accounting Concept (SFAC) No. 1, salah satu komponen penting dan menjadi perhatian para pembaca laporan keuangan adalah tentang hasil kinerja operasional perusahaan yang tercermin dari laba yang dilaporkan. Manajer sebagai pengelola perusahaan tentunya mengetahui lebih banyak informasi internal dan prospek perusahaan di masa yang akan datang dibandingkan pemilik. Oleh karena itu, manajer sebagai agen berkewajiban memberikan sinyal mengenai kondisi perusahaan yang sesungguhnya kepada pemilik. Akan tetapi, informasi yang disampaikan terkadang tidak sesuai dengan kondisi perusahaan yang sesungguhnya. Hal tersebut akan menimbulkan ketidaksesuaian informasi yang disampaikan oleh manajemen kepada para investor sehingga memicu munculnya suatu kondisi yang disebut asimetri informasi (Ujiyanto \& Pramuka, 2007).

Adanya ketidakterbukaan informasi dan adanya benturan kepentingan kepentingan antara agen dan prinsipal menyebabkan tidak diungkapkannya semua informasi kepada publik secara jelas, terutama kepada para investor (Jensen dan Meckling, 1976) Untuk mengantisipasi terjadinya asimetri informasi, diperlukan suatu mekanisme yang dapat meminimalkan tingkat asimetri informasi yang dilakukan oleh agent kepada principal. Salah satu mekanisme yang dapat digunakan adalah konsep corporate governance yang merupakan sistem, struktur, dan proses yang terintegrasi untuk mewujudkan kelima prinsip utama dari corporate governance, yaitu transparency, accountability, responsibility, independency, dan fairness. Pelaksanaan corporate governance memerlukan adanya struktur yang ideal seperti komisaris independen, komite audit, direksi, dan komite penunjang lainnya.

Fama (1980) dalam Eng dan Mak (2003) menyatakan bahwa komisaris independen merupakan sentral mekanisme kontrol internal perusahaan dalam melakukan pengawasan terhadap manajer. Beberapa penelitan telah melaporkan hasil penelitian tentang hubungan komite audit dan kualitas pelaporan keuangan. Beberapa penelitian cenderung untuk mendukung keberadaan komite audit karena meningkatkan kualitas pelaporan keuangan (Klien, 2002; DeFond dan Jiambalvo, 1994; Beasly dan Salterio, 2001). Di sisi lain hasil penelitian tidak menemukan perbedaan antara perusahaan yang membentuk dan tidak membentuk komite audit (Beasley, 1996; Kalbers, 1992; Crowford, 1987 di dalam McMullen, 1996).

Peningkatan struktur kepemilikan dalam 
Dinamika Sosial Budaya, Vol 20, No. 1, Juni 2018, pp 50-56 p-ISSN: 1410-9859\& e-ISSN: 2580-8524

http://journals.usm.ac.id/index.php/jdsb

suatu perusahaan diharapkan akan membuat manajer dapat bertindak sesuai dengan keinginan pemegang saham, karena manajer secara otomatis akan termotivasi untuk meningkatkan kinerja. Selanjutnya (Pratiwi, Nurkholis, \& Ghofar, 2015) corporate governance dan kepemilikan institusional tidak terbukti berpengaruh negatif terhadap asimetri informasi. Sedangkan kepemilikan manajerial terbukti berpengaruh negatif dan signifikan terhadap asimetri informasi. Hasil penelitian dari variabel kontrol ukuran perusahan dan volume perdagangan tidak berpengaruh terhadap asimetri informasi, sedangkan varian return berpengaruh negatif terhadap asimetri informasi.

\subsection{Rumusan Masalah}

Berdasarkan uraian yang dipaparkan pada latar belakang maka permasalahan yang akan dibahas dalam penelitian ini antara lain: apakah terdapat pengaruh antara komisaris independen, komite audit, kualitas audit, kepemilikan institusional dan kepemilikan manajerial terhadap asimetri informasi?

\subsection{Tujuan dan Kegunaan Penelitian}

Adapun tujuan penelitian yaitu untuk mengetahui pengaruh komisaris independen, komite audit, kualitas audit, kepemilikan institusional dan kepemilikan manajerial terhadap asimetri informasi.

Hasil dari penelitian ini diharapkan dapat memberikan manfaat sebagai berikut:

1. Bagi Perusahaan, sebagai bahan referensi kepada perusahaan mengenai pengaruh komisaris independen, komite audit, kualitas audit, kepemilikan institusional dan kepemilikan manajerial terhadap asimetri informasi.

2. Bagi investor, sebagai sumber informasi dan dasar pertimbangan dalam pengambilan keputusan sebelum melakukan investasi

3. Bagi akademisi, sebagai bahan referensi untuk melakukan penelitian selanjutnya yang berkaitan.

\subsection{Kerangka konseptual Penelitian}

Kerangka konseptual pada penelitian ini adalah sebagai berikut :

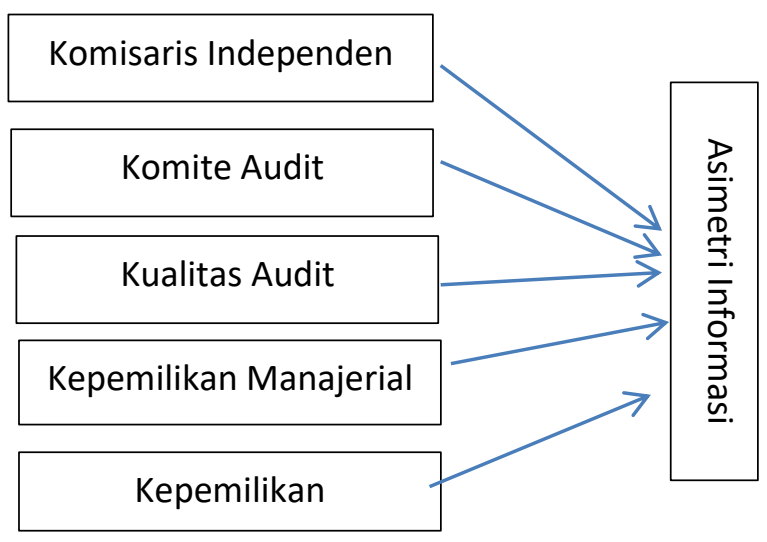

\section{Metode Penelitian}

\section{METODE PENELITIAN}

Variabel dependen dalam penelitian ini adalah asimetri informasi. Asimetri informasi adalah suatu keadaan dimana agent memiliki informasi yang lebih banyak tentang perusahaan dimasa yang akan datang dibandingkan dengan principal. Penelitian ini mengukur asimetri informasi dengan menggunakan bid-ask spread. Model untuk menyesuaikan perhitungan Asimetri Informasi (Kanagaretnam, Gerald, and Dennis 2007) dalam penelitian ini sebagai berikut: Asimetri Informasi $=($ Ask-bid $) /\{($ Ask + bid $) / 2\}$ 
Dinamika Sosial Budaya, Vol 20, No. 1, Juni 2018, pp 50-56 p-ISSN: 1410-9859\& e-ISSN: 2580-8524

http://journals.usm.ac.id/index.php/jdsb

Ask adalah Harga permintaan tertinggi saham perusahaan i pada tahun $\mathrm{t}$

Bid adalah Harga penawaran terendah saham perusahaan I pada tahun $\mathrm{t}$

Variabel independen yang digunakan ada lima, yaitu komisaris independen, komite audit, kualitas audit, kepemilikan institusional dan kepemilikan manajerial. Penelitian ini juga menyertakan variabel Kontrol yang digunakan, yaitu: (1) ukuran perusahaan (size) yang diukur dengan total asset perusahaan; (2) volume perdagangan yaitu penutupan pasar bulanan yang kemudian diratarata dalam satu tahun,dan; (3) varian return yang diukur dengan:

$\mathrm{R}=(\mathrm{Pt}-\mathrm{Pt}-1) /(\mathrm{Pt}-1)$

$\mathrm{R}=$ return saham

$\mathrm{Pt}=$ harga saham pada tahun ke $\mathrm{t}$

Pt-

1 = harga saham pada tahun $\mathrm{t}-1$

Sampel penelitian ini adalah perusahaan manufaktur yang terdaftar pada BEI selama tahun 2015 - 2017. Data penelitian ini menggunakan data sekunder yang diambil melalui website idx.com dan website resmi perusahaan.

\section{HASIL DAN PEMBAHASAN}

Pengambilan sampel dilakukan dengan metode purposive sampling. Kriteria yang ditetapkan untuk memilih perusahaan yang dijadikan sampel adalah: (1) Perusahaan telah mempublikasikan laporan tahunan (annual report) secara terus menerus sejak tahun 2015 sampai 2017 disitus resmi IDX atau website resmi perusahaan, (ii) perusahaan tidak melakukan stock split, (iii) perusahaan menggunakan mata uang rupiah dalam laporan keuangan. Berdasarkan kriteria pemilihan sampel tersebut diperoleh sampel sebanyak 77 perusahaan. Penelitian ini menggunakan 3

periode, sehingga hasil sampel diperoleh $3 \times 77$

$=231$. Adapun rinciannya sebagai berikut:

\section{Tabel 3.1}

Sampel Penelitian

\begin{tabular}{|l|l|l|}
\hline $\begin{array}{l}\text { Perusahaan manufaktur yang terdaftar di BEI } \\
\text { peiode } 2015-2017\end{array}$ & $:$ & 143 \\
\hline $\begin{array}{l}\text { Annual report perusahaan yang tidak dapat } \\
\text { diakses }\end{array}$ & $:$ & 32 \\
\hline $\begin{array}{l}\text { Laporan Keuangan perusahaan yang } \\
\text { menggunakan mata uang selain rupiah }\end{array}$ & $:$ & 30 \\
\hline Perusahaan yang melakukan stock split & $:$ & 4 \\
\hline $\begin{array}{l}\text { Perusahaan yang memenuhi kriteria sebagai } \\
\text { sampel }\end{array}$ & $:$ & 77 \\
\hline Periode (jumlah tahun pengamatan & $:$ & 3 \\
\hline Jumlah sampel & $:$ & 231 \\
\hline
\end{tabular}

Sumber: data sekunder diolah 2018.

Berdasarkan tabel diatas menjelaskan bahwa dari 143 perusahaan manufaktur yang terdaftar di BEI yang memenuhi kriteria terdapat 77 perusahaan yang dapat dijadikan sampel pada penelitian ini. Kriteria tersebut antara lain:

(1) Perusahaan telah mempublikasikan laporan tahunan secara terus menerus tahun 20152017 disitus resmi IDX atau website resmi perusahaan,

(2) Perusahaan tidak melakukan stock split,

(3) Perusahaan menggunakan mata uang rupiah dalam laporan keuangan.

\section{a. Uji Asumsi Klasik}

Dari pengujian asumsi klasik yang dilakukan data yang digunakan dalam penelitian ini sudah memenuhi asumsi normalitas (data terdistribusi normal), tidak ada multikolinearitas antar variabel independen dalam model regresi ini, tidak terjadi autokorelasi antar nilai residual. tidak terdapat gangguan heterokedastisitas pada model regresi

\subsection{Hasil Penelitian}


Dinamika Sosial Budaya, Vol 20, No. 1, Juni 2018, pp 50-56

p-ISSN: 1410-9859\& e-ISSN: 2580-8524

http://journals.usm.ac.id/index.php/jdsb

\section{Uji F}

Uji $\mathrm{F}$ diperlukan untuk mengetahui pengaruh variabel independen terhadap variabel dependen secara simultan dan untuk mengetahui ketepatan model regresi yang digunakan. Uji ketepatan model bertujuan untuk mengetahui apakah perumusan model tepat atau fit.

Tabel 3.2

Hasil Uji F

ANOVA $^{b}$

\begin{tabular}{|c|c|c|c|c|c|}
\hline Model & $\begin{array}{l}\text { Sum of } \\
\text { Squares }\end{array}$ & df & $\begin{array}{l}\text { Mean } \\
\text { Square }\end{array}$ & $\mathrm{F}$ & Sig. \\
\hline 1 Regression & 4,072 & 8 & ,509 & 4,211 &, $000^{\mathrm{a}}$ \\
\hline Residual & 26,832 & 222 & , 121 & & \\
\hline Total & 30,904 & 230 & & & \\
\hline
\end{tabular}

a. Predictors: (Constant), LnVol, Return Saham,

Kepemilikan Manajerial, Komisaris Independen,

Kualitas Audit, Kepemilikan Institusi, Komite

Audit, LnSize

b. Dependent Variable: Asimetri informasi

Hasil uji F diperoleh nilai Fhitung sebesar $(4,211)>$ F tabel ( 2,81 ) dengan nilai signifikannya sebesar 0,000 pada tingkat signifikan 0,05 maka dapat disimpulkan bahwa model regresi yang dipilih sudah tepat digunakan dalam penelitian ini atau model regresi yang digunakan adalah fit.

\section{Koefisien Determinasi}

Koefisien Determinasi berfungsi untuk mengukur proporsi atau presentasi sumbangan dari seluruh variabel bebas $(\mathrm{X})$ yang terdapat dalam model regresi terhadap variabel terikat $(\mathrm{Y})$.

Tabel 3.3

Uji Koefisien Determinasi Model Summary ${ }^{b}$

\begin{tabular}{|l|l|l|l|l|l|}
\hline $\begin{array}{l}\text { Mo } \\
\text { del }\end{array}$ & $\mathrm{R}$ & $\begin{array}{l}\mathrm{R} \\
\text { Squar } \\
\mathrm{e}\end{array}$ & $\begin{array}{l}\text { Adjusted } \\
\mathrm{R} \text { Square }\end{array}$ & $\begin{array}{l}\text { Std. Error } \\
\text { of the } \\
\text { Estimate }\end{array}$ & $\begin{array}{l}\text { Durbin- } \\
\text { Watson }\end{array}$ \\
\hline 1 &, $363^{\mathrm{a}}$ &, 132 &, 100 &, 34766 & 2,105 \\
\hline
\end{tabular}

Model Summary ${ }^{b}$

\begin{tabular}{|l|l|l|l|l|l|}
\hline $\begin{array}{l}\text { Mo } \\
\text { del }\end{array}$ & $\mathrm{R}$ & $\begin{array}{l}\text { Rquar } \\
\mathrm{e}\end{array}$ & $\begin{array}{l}\text { Adjusted } \\
\text { R Square }\end{array}$ & $\begin{array}{l}\text { Std. Error } \\
\text { of the } \\
\text { Estimate }\end{array}$ & $\begin{array}{l}\text { Durbin- } \\
\text { Watson }\end{array}$ \\
\hline 1 &, $363^{\mathrm{a}}$ &, 132 &, 100 &, 34766 & 2,105 \\
\hline
\end{tabular}

a. Predictors: (Constant), LnVol, Return Saham,

Kepemilikan Manajerial, Komisaris Independen,

Kualitas Audit, Kepemilikan Institusi, Komite Audit, LnSize

b. Dependent Variable: Asimetri informasi

Koefisien determinasi Hasil dari output pada tebel menunjukkan besarnya nilai $\mathrm{R}$ Square sebesar 0,100. Hal ini menunjukkan bahwa Adjust R2 menggambarkan variasi perubahan asimetri informasi sekitar $10 \%$ dapat dijelaskan oleh pengungkapan sukarela. Nilai Adjust R2 yang kecil berarti kemampuan variabel independen menjelaskan bahwa variabel dependen masih kurang dan masih perlu adanya penambahan variabel independen. Sedangkan sisanya 90\% dijelaskan oleh variabel lain.

\section{Uji t}

Analisis regresi ditujukan untuk mengukur kekuatan hubungan antara dua variabel atau lebih, juga menunjukan arah hubungan antara variabel dependen dengan variabel independen. Hasil dari pengujian regresi berganda adalah sebagai berikut

Tabel 3.4

Hasil Uji t

Coefficients $^{\mathrm{a}}$

\begin{tabular}{|c|c|c|c|c|c|}
\hline \multirow[b]{2}{*}{ Model } & \multicolumn{2}{|c|}{$\begin{array}{l}\text { Unstandardized } \\
\text { Coefficients }\end{array}$} & \multirow{2}{*}{$\begin{array}{l}\text { Standardize } \\
\text { d } \\
\text { Coefficients } \\
\text { Beta }\end{array}$} & \multirow[b]{2}{*}{$\mathrm{t}$} & \multirow[b]{2}{*}{ Sig. } \\
\hline & $\mathrm{B}$ & Std. Error & & & \\
\hline $1 \quad$ (Constant) & 1,340 & ,468 & & 2,861 & $\begin{array}{l}, 00 \\
5\end{array}$ \\
\hline $\begin{array}{l}\text { Komisaris } \\
\text { Independen }\end{array}$ &,- 026 & ,208 &,- 008 &,- 126 & $\begin{array}{l}, 90 \\
0\end{array}$ \\
\hline $\begin{array}{l}\text { Komite } \\
\text { Audit }\end{array}$ &,- 045 &, 053 &,- 058 &,- 861 & $\begin{array}{l}, 39 \\
0\end{array}$ \\
\hline $\begin{array}{l}\text { Kualitas } \\
\text { Audit }\end{array}$ &,- 022 &, 057 &,- 028 &,- 385 & $\begin{array}{l}, 70 \\
0\end{array}$ \\
\hline
\end{tabular}


Dinamika Sosial Budaya, Vol 20, No. 1, Juni 2018, pp 50-56

p-ISSN: $1410-9859 \&$ e-ISSN: 2580-8524

http://journals.usm.ac.id/index.php/jdsb

\begin{tabular}{|l|l|l|l|l}
\hline $\begin{array}{l}\text { Kepemilika } \\
\text { n Institusi }\end{array}$ &, 002 &, 001 &, 142 \\
$\begin{array}{l}\text { Kepemilika } \\
\mathrm{n}\end{array}$ &, 001 &, 002 &, 035 \\
$\begin{array}{l}\text { Manajerial } \\
\text { LnSize }\end{array}$ &,- 033 &, 017 &,- 147 \\
LnVol &, 020 &, 009 &, 140 \\
Return &, 052 &, 012 &, 272 & \\
Saham & & & & \\
\hline
\end{tabular}

a. Dependent Variable: Asimetri informasi

\subsection{Pembahasan}

Berdasarkan out put hasil penelitian yang dijelaskan diatas menunjukkan bahwa hanya variable kepemilikan institusional (X4) yang berpengaruh secara signifikan terhadap asimetri informasi. Sedangkan variable lain tidak memiliki pengaruh terhadap asimetri informasi. Berikut adalah hasil penelitian adalah

\section{Pengaruh Komisaris Independen Terhadap Asimetri Informasi}

Hasil pengujian variabel Komisaris Independen terhadap asimetri informasi menunjukkan bahwa variabel tersebut mempunyai nilai signifikansi 0,900 (nilai signifikansi $t>0,05$ ) maka hal ini berarti bahwa variabel Komisaris Independen secara terpisah (parsial) tidak berpengaruh negatif signifikan terhadap asimetri informasi. Dengan demikian Hipotesis 1 ditolak.

Hasil pengujian menunjukkan bahwa variabel ukuran dewan komisaris independen tidak memiliki pengaruh yang signifikan terhadap asimetri informasi.. Besar kecilnya ukuran dewan komisaris bukanlah menjadi faktor penentu utama dari efektivitas pengawasan terhadap manajemen perusahaan. (Daljono dan Raharjo 2014)
2,193 24,0 Bengaruh Komite Audit Terhadap Asimetri
,517 terhadap asimetri informasi. Dengan demikian Hipotesis 2 ditolak.

Hasil penelitian menunjukkan bahwa komite audit tidak berpengaruh terhadap asimetri informasi. Jika dilihat jumlah rata-rata komite audit pada perusahaan yang menjadi sampel berjumlah 3 orang, artinya perusahaan sudah mengikuti aturan dari Bapepam. Tetapi dengan jumlah komite audit tersebut tidak mampu mengurangi asimetri informasi.

\section{Pengaruh Kualitas Audit Terhadap Asimetri} Informasi

Hasil pengujian variabel Kualitas Audit terhadap asimetri informasi menunjukkan bahwa variabel tersebut mempunyai nilai signifikansi 0,700 (nilai signifikansi $\mathrm{t}>0,05$ ) maka hal ini berarti bahwa variabel kualitas audit secara terpisah (parsial) tidak berpengaruh negatif signifikan terhadap asimetri informasi. Dengan demikian Hipotesis 3 ditolak.

Hasil penelitian menunjukkan bahwa keualitas audit tidak berpengaruh terhadap asimetri informasi. Perusahaan yang menjadi sampel penelitian ini diaudit oleh KAP Non-Big 4 sebanyak 76,5\% sedang diaudit oleh Big 4 sebesar $32,5 \%$. 
Dinamika Sosial Budaya, Vol 20, No. 1, Juni 2018, pp 50-56

p-ISSN: $1410-9859 \&$ e-ISSN: 2580-8524

http://journals.usm.ac.id/index.php/jdsb

\section{Pengaruh Kepemilikan Institusi Terhadap} Asimetri Informasi

Hasil pengujian variabel Kepemilikan Instituasi terhadap asimetri informasi menunjukkan bahwa variabel tersebut mempunyai nilai signifikansi 0,029 (nilai signifikansi $\mathrm{t}<0,05$ ) maka hal ini berarti bahwa variabel kepemilikan instituasi secara terpisah (parsial) tidak berpengaruh negatif signifikan terhadap asimetri informasi. Dengan demikian Hipotesis 4 diterima.

Hasil penelitian ini menunjukkan bahwa kepemilikan institusional berpengaruh terhadap asimetri informasi. Hasil penelitian ini didukung oleh penelitian yang dilakukan oleh Purwanti (2013). Dalam penelitiannya Purwanti (2013) menghasilkan tidak adanya hubungan negative antara kepemilikan institusional dan asimetri informasi.

\section{Pengaruh Kepemilikan Manajerial Terhadap Asimetri Informasi}

Hasil pengujian variabel Kepemilikan Manajerial terhadap asimetri informasi menunjukkan bahwa variabel tersebut mempunyai nilai signifikansi 0,606 (nilai signifikansi t $>0,05$ ) maka hal ini berarti bahwa variabel kepemilikan manajerial secara terpisah (parsial) tidak berpengaruh negatif signifikan terhadap asimetri informasi. Dengan demikian Hipotesis 5 ditolak.

Hasil penelitian menunjukkan bahwa kepemilikan manajerial tidak berpengaruh terhadap asimetri informasi. Hasil penelitian ini berbeda dengan penelitian yang dilakukan oleh Purwanti (2013) dan Crutchley dan Hansen (1989). Penelitian-penelitian tersebut menyimpulkan bahwa kepemilikan manajerial yang tinggi dapat mengurangi masalah keagenan.

\section{KESIMPULAN}

Hasil penelitian menunjukkan bahwa corporate governance yang terdiri dari variable komisaris independen,komite audit dan kualitas audit, tidak berpengaruh terhadap asimetri informasi. Hasil penelitian ini tidak sejalan dengan teori yang menyatakan bahwa corporate governance memiliki peran untuk pengawasan sehingga akan memberikan keyakinan kepada investor bahwa dana yang diinvestasikan aman. Tidak adanya pengaruh ini dikarenakan penerapan corporate governance yang ada di Indonesia cenderung tertinggal dari negara-negara lain, sehingga menyebab- kan tdak adanya pengaruh yang signifikan.

Hasil penelitian yang menguji pengaruh struktur kepemilikan terhadap asimetri informasi menunjukkan bahwa struktur kepemilikan institusional berpengaruh terhadap asimetri informasi. Hal ini dikarenakan Kepemilikan saham oleh institusi juga memiliki akses atas informasi yang terlalu mahal perolehannya bagi investor lain. Investor institusional akan melakukan monitoring secara efektif dan tidak akan mudah diperdaya dengan tindakan manipulasi yang dilakukan manajer.

Sedangkan untuk kepemilikan manajerial, terdapat tidak pengaruh yang signifikan dengan koefisien negatif terhadap asimteri informasi. Hasil penelitian ini berbeda dengan teori, Kondisi tersebut dapat terjadi karena presentase manajemen yang memiliki saham relatif sangat kecil jika dibandingkan dengan keseluruhan modal yang dimiliki investor umum.

\section{DAFTAR PUSTAKA}

Haryati, Nurul, \& Baridwan, Z. (2011). Pengaruh Mekanisme Corporate Governance Terhadap Kinerja: Transparasi Sebagai 
Dinamika Sosial Budaya, Vol 20, No. 1, Juni 2018, pp 50-56

p-ISSN: 1410-9859\& e-ISSN: 2580-8524

http://journals.usm.ac.id/index.php/jdsb

Variabel Intervening. Simposium Nasional Akuntansi XIV.

Jensen, M. C., \& Meckling, W. H. (1976). Theory of Form: Managerial Behaviour, Agency Cost, and Ownershi Structure. Journal of Financial Economics.

Kanagaretman, K. L., Gerald, J. L., \& Dennis, J. W. (2007). Does Corporate Governance Reduce Information Asymetry Around Quarterly Earnings Anouncement? Journal Of Accounting and Public Policy, 4(26).

Pratiwi, A., Nurkholis, \& Ghofar, A. (2015). Pengaruh Corporate Governance dan
Strukur Kepemilikan Terhadap Asimetri Informasi. Jurnal Akuntansi dan Auditing Indonesia.

Purwanti, T. (2013). The Impact of Corporate Governance Mechanism on The Asymetry information. Jurnal Kiat BISNIS, 2(5).

Raharjo, A. S., \& Daljono. (2014). Pengaruh Ukuran Dewan Komisaris, Direksi, Komisaris Independen, Struktur Kepemilikan, dan Indeks Corporate Governance Terhadap Asimetri Informasi. Diponegoro Journal of Accounting, 3(3) 